\title{
PERDA SEBAGAI BAGIAN HUKUM DI INDONESIA
}

\author{
H Muhammad Kasim \\ STIA Al Gazali Barru
}

\begin{abstract}
Abstrak
Perda adalah peraturan untuk melaksanakan aturan-aturan hukum diatasnya dan menampung kondisi khusus di daerah. Perda adalah Peraturan Perundang-undangan yang dibentuk oleh DPRD dengan persetujuan bersama Kepala Daerah. Kepala Daerah menetapkan Perda atas persetujuan DPRD dalam rangka penyelenggaraan Otonomi Daerah dan penjabaran lebih lanjut dari peraturan perundang-undangan yang lebih tinggi. Oleh karena itu Perda tidak boleh bertentangan dengan kepentingan umum, Perda lainnya dan peraturan perundang-undangan yang lebih tinggi. Dalam melaksanakan Perda dan atas kuasa peraturan perundang-undangan lain yang berlaku, maka Kepala Daerah menetapkan keputusan Kepala Daerah. Perda dan keputusan Kepala Daerah bersifat mengatur diundangkan dengan menempatkannya dalam Lembaran Daerah. Untuk pelaksanaan otonomi daerah, maka Perda berperanan untuk mengatur dan sekaligus sebagai instrumen pelaksanaan otonomi daerah yang bertanggungjawab.
\end{abstract}

Kata Kunci : Peraturan Daerah, Perda, Hukum Indonesia

\section{Pendahuluan}

\section{Pemerintahan Daerah}

dibentuk atas dasar Pasal 18 UndangUndang Dasar 1945 yang menyatakan bahwa : Pembagian Daerah di Indonesia atas Daerah besar dan kecil dengan bentuk susunan pemerintahannya ditetapkan dengan undang-undang, dengan memandang dan mengingat dasar permusyawaratan dalam sistem pemerintahan negara dan hak-hak, asal-usul dalam daerahdaerah yang bersifat istimewa.

$$
\text { Berdasarkan penjelasan }
$$

tersebut di atas, maka negara Indonesia itu, seperti dijelaskan di dalam penjelasan Undang-Undang Dasar 1945 adalah suatu eenheidsstaat, maka Indonesia tak akan mempunyai daerah di dalam lingkungannya yang bersifat staat juga. Daerah Indonesia akan dibagi dalam daerah propinsi dan daerah propinsi akan dibagi pula dalam daerah yang lebih kecil. Di daerah yang bersifat otonom (Streek dan locate rechtgemeenshappen) atau bersifat daerah administrasi belaka, semuanya menurut aturan yang akan ditetapkan dengan undang-undang. Di daerah-daerah yang bersifat otonom akan diadakan badan perwakilan daerah. Oleh karena itu, di daerah pun pemerintahan akan bersendi atas dasar permusyawaratan.

Kemudian daripada itu, dalam teritoir negara Indonesia terdapat lebih $\begin{array}{lll}\text { kurang } & 250 \quad \text { Zelfbestuurende }\end{array}$ landschappen dan Volksgemennschappen, seperti seperti Jawa dan Bali, negeri di Mingkabau, dusun dan marga di Palembang dan sebagainya dapat dianggap sebagai daerah yang bersifat istimewa.

Negara Indonesia menghormati kedudukan daerahdaerah istimewa tersebut dan segala peraturan negara yang mengenai daerah-daerah itu akan mengingati hak hak asal usul daerah tersebut. 
Dari ketentuan pasal 18 Undang-Undang Dasar 1945 beserta penjelasannya maka dapat ditarik beberapa hal sebagai berikut : (1) Wilayah Indonesia dibagi ke dalam daerah-daerah baik daerah yang bersifat otonom maupun yang bersifat administratif; (2) Daerah-daerah itu mempunyai pemerintahan; (3) Pembagian wilayah dan bentuk susunan pemerintahannya ditetapkan dengan undang-undang; (4) Dalam pembentukan daerah-daerah itu, terutama daerah-daerah otonom dan dalam menentukan susunan pemerintahannya harus diingat dasar permusyawaratan dalam sistem pemerintahan Negara dan hak-hak asal usul dalam daerah-daerah yang bersifat istimewa (asli). Dalam hal ini, Soegeng Istanto dalam Riwu Kaho (1982) menyimpukan bahwa (1) Daerah tidaklah bersifat staat; (2) Wilayah Indonesia mula-mula akan dibagi dalam propinsi-propinsi dan propinsi-propinsi ini kemudian dibagi lagi dalam daerah-daerah yang lebih kecil; (3) Daerah ini bisa bersifat otonom dan bisa pula bersifat administratif; (4) Di Daerah otonom dibentuk Badan Perwakilan Daerah sesuai dengan dasar permusyawaratan dalam sistem pemerintahan negara. Dari uraian di atas maka jelas bahwa Negara Republik Indonesia adalah Negara Kesatuan yang didesentralisasikan.

Sehubungan dengan itu, maka pada dasarnya hubungan kekuasaan antara Pemerintah Pusat dan Pemerintah Daerah dapat dikemukakan bahwa yang memegang kekuasan tertinggi atas segenap urusan Negara ialah Pemerintah Pusat (Central Goverment) tanpa adanya gangguan oleh suatu delegasi atau pelimpahan kekuasaan kepada

Pemerintah Daerah (Regional

Goverment). Dalam suatu Negara

Kesatuan terdapat azas bahwa segenap urusan-urusan Negara tidak dibagi antara Pemerintah Pusat (Central Goverment) dengan Pemerintah Daerah (Local Goverment) sedemikian rupa, sehingga urusan-urusan Negara dalam Negara Kesatuan itu tetap merupakan suatu kebulatan (eenheid) dan bahwa pemegang kekuasaan tertinggi di negara itu adalah Pemerintah Pusat. Ini berarti bahwa dalam Negara Kesatuan yang menganut sistem desentralisasi (otonomi), Pemerintah Pusat tetap mempunyai hak untuk mengawasi Daerah-Daerah yang berhak dan berkewajiban untuk mengatur dan mengurus rumah tangganya sendiri. Wewenang untuk mengatur dan mengurus rumah tangganya itu berasal dari/atau merupakan pelimpahan dari Pemerintah Pusat. Undang-Undang Nomor 32 Tahun 2004 tentang Pemerintahan Daerah sebagai pengganti UndangUndang Nomor 22 tahun 1999 yang dibentuk pada era reformasi merupakan wujud nyata dari amanah konstitusi. Dengan demikian pula terhadap undang-undang pemerintahan daerah yang dibentuk sebelumnya, seperti Undang-Undang Nomor 5 tahun 1974 dan undangundang pemerintahan daerah lainnya, pada dasarnya merupakan pelaksanaan pasal 18 Undang Undang Dasar 1945, walaupun dengan prinsip otonomi daerah yang berebeda.

Undang-undang Nomor 32 tahun 2004, menggunakan prinsip otonomi seluas-luasnya dan prinsip otonomi nyata dan bertanggungjawab. Prinsip otonomi daerah seluas-luasnya 
dimaksudkan daerah otonom diberikan kewenangan mengatur dan mengurus semua urusan pemerintahan di luar yang menjadi urusan Pemerintah. Daerah memiliki kewenangan membuat kebijakan berupa Perda untuk memberikan pelayanan, peningkatan peran serta, prakarsa, dan pemberdayaan masyarakat yang bertujuan pada peningkatan kesejahteran masyarakat.

Oleh karena itu dengan diberikannya wewenang yang seluasluasnya kepada daerah untuk berotonomi, setelah diundangkannya dua undang-undang tentang Pemerintahan Daerah, tidak berarti Pemerintah Daerah seenaknya saja menggunakan hak dan kewajibannya untuk mengatur dan mengurus rumah tangganya sendiri tanpa mengabaikan koordinasi dan pengawasan Pemerintah Pusat, karena bila demikian akan dikhawatirkan di dalam pelaksanaan desentralisasi yang seluas-luasnya atau otonomi yang seluas-luasnya terdapat daerah yang bersemangat untuk mengelola potensi daerahnya, sementara beberapa daerah lainnya, karena berbagai keterbatasan yang dimiliki sulit berkembang sehingga pada akhirnya sangat tertinggal dibanding daerah-daerah lainnya, yang dapat menimbulkan kecemburuan sosial.

Agar daerah dapat melaksanakan otonominya secara bertanggungjawab maka setiap daerah berhak menetapkan kebijakankebijakannya sendiri terutama dalam menggali potensi daerahnya masingmasing, melalui Perda dan Peraturan Kepala Daerah.

Menurut penjelasan UndangUndang Nomor 32 Tahun 2004 tentang Pemerintahan Daerah, bahwa penyelenggaraan pemerintahan daerah dalam melaksanakan tugas, wewenang, kewajiban dan tanggungjawabnya serta atas kuasa peraturan perundang-undangan yang lebih tinggi dapat menetapkan kebijakan daerah yang dirumuskan antara lain dalam Perda, peraturan kepala daerah, dan ketentuan daerah lainnya. Kebijakan daerah dimaksud tidak boleh bertentangan dengan peraturan perundang undangan yang lebih tinggi dan kepentingan umum serta Perda lainnya. Perda dibuat oleh DPRD bersama Pemerintah Daerah, artinya prakarsa dapat berasal dari DPRD maupun dari Pemerintah Daerah. Khusus Perda tentang APBD rancangannya disiapkan oleh Pemerintah Daerah yang telah mencakup keuangan DPRD, untuk dibahas bersama DPRD. Perda dalam ketentuan daerah lainnya yang bersifat mengatur diundangkan dengan menempatkannya dalam Lembaran Daerah. Perda tertentu yang mengatur pajak daerah, retribusi daerah, APBD, perubahan APBD, dan tata ruang, berlakunya setelah melalui tahapan evaluasi oleh Pemerintah. Hal itu ditempuh dengan pertimbangan antara lain untuk melindungi kepentingan umum, menyelaraskan dan menyesuaikan dengan peraturan perundangan yang lebih tinggi dan/atau Perda lainnya, terutama Perda mengenai pajak daerah dan retribusi daerah.

Sehubungan dengan kerangka pemikiran tersebut di atas maka masalah yang akan dibahas dalam tulisan ini adalah bagaimana kedudukan dan fungsi Perda sebagai instrumen aturan otonomi daerah dalam sistem hukum nasional, dengan tujuan untuk mengetahui kedudukan 
dan fungsi Perda sebagai instrumen aturan otonomi daerah. Tulisan ini diharapkan bermanfaat sebagai bahan kritisi untuk lebih meningkatkan peran Perda dimasa mendatang, dan mendudukkan Perda sebagai perangkat hukum formal dalam rangka sistem hukum nasional.

\section{Pembahasan}

Kedudukan Peraturan

Perundang-Undangan dalam Negara Indonesia sangat dominan, mengingat Undang-Undang Dasar 1945 hasil amandemen keempat pada pasal 1 ayat (3) menyatakan Indonesia merupakan negara hukum. Untuk itu negara / pemerintah mengembang amanat untuk melakukan pembentukan hukum untuk menjalankan tugas dan tanggungjawabnya dalam mencapai tujuan kesejahtertaan masyarakat. Menurut Ryaas Rasyid (1997 : 16) pemerintah selaku penyelenggara negara memiliki tujuh tugas pokok yang diemban pemerintah antara lain (1) memelihara keamanan negara (2) menjamin ketertiban, (3) menjamin perlakuan adil bagi setiap warga, (4) melakukan pekerjaan umum, (5) melakukan upaya peningkatan kesejahteraan sosial (6) menerapkan kebijakan ekonomi, dan (7) pengelolaan serta pemeliharaan sumber daya alam dan lingkungan hidup. Untuk mengembang seluruh tugas tersebut diperlukan konstitusi, hukum, etika, dan lembaga-lembaga yang tangguh serta jajaran yang kualifaid.

Dalam pembentukan peraturan perundang-undangan termasuk di dalamnya Perda, berdasarkan UndangUndang Nomor 10 Tahun 2004 tentang Pembentukan Peraturan Perundang-Undangan Pasal 5, bahwa asas pembentukan perundangundangan meliputi kejelasan tujuan, kelembagaan atau organ pembentukan yang tepat, kesesuaian antara jenis dan materi muatan, dapat dilaksanakan, kedayagunaan dan kehasilgunaan kejelasan rumusan, dan keterbukaan.

Untuk melaksanakan pemerintah daerah secara baik maka salah satu persyaratan adalah berbagai Perda harus diterbitkan dan ditetapkan sebagai tuntutan dari Undang-undang pemerintahan daerah, antara lain tentang APBD yang harus diatur berdasarkan Perda. Perda itu disetujui lebih dahulu oleh DPRD sebelum Kepala Daerah menetapkannya, dengan kata lain kewenangan menetapkan Perda adalah Kepala Daerah. Perda tidak boleh bertentangan dengan kepentingan umum, Perda yang lain, dan peraturan perundang-undang yang lebih tinggi. Pemerintah dapat membatalkan Perda yang bertentangan dengan kepentingan umum atau peraturan perundang-undangan yang lebih tinggi dan atau peraturan perundangundangan lainnya, dengan berbagai alasan dan pertimbangan. Namun demikian Daerah yang tidak dapat menerima keputusan pembatalan Perda, dapat mengajukan kepada Mahkamah Agung setelah mengajukan kepada Pemerintah.

\section{Pembentukan Hukum}

Untuk memahami mengenai proses penyusunan rancangan Perda maka berikut ini diuraikan kedudukan Perda, prosedur pembahasan, pengesahan dan pengundangan. Berdasarkan Undang-Undang Nomor 10 Tahun 2004 Tentang Pembentukan Peraturan Perundang Undangan, Peraturan Daerah adalah Peraturan 
Perundang Undangan yang dibentuk oleh DPRD dengan persetujuan bersama Kepala Daerah. Sedangkan pengertian Perda sebagaimana yang ditetapkan dalam TAP MPR Nomor III Tahun 2000, Perda adalah peraturan untuk melaksanakan aturanaturan hukum di atasnya dan menampung kondisi khusus di daerah.

Pengertian Perda sebagaimana yang diungkapkan di atas menunjukkan bahwa Perda merupakan instrumen aturan yang secara sah diberikan kepada pemerintah daerah dalam penyelenggaraan pemerintahan di daerah. Kedudukan Perda sendiri dalam hirarki perundang undangan berdasarkan TAP MPR Nomor III Tahun 2000 tentang Sumber Hukum dan tata urutan perundang-undangan yaitu : (1) Undang-Undang Dasar 1945 merupakan hukum dasar tertulis Negara RI; (2) Ketetapan MPR merupakan putusan MPR sebagai pengembang kedaulatan rakyat; (3) Undang-Undang untuk melaksanakan UUD 1945 serta Ketetapan MPR RI;

(4) Peraturan Pemerintah Pengganti Undang-Undang dibuat dalam hal ihwal kegentingan yang memaksa; (5) Peraturan Pemerintah dibuat untuk melaksanakan perintah undangundang, (6) Keputusan Presiden bersifat mengatur untuk menjalankan fungsi dan tugasnya untuk mengatur pelaksanaan administrasi negara dan administrasi pemerintahan dan; (7) Peraturan Daerah (Perda) merupakan peraturan untuk melaksanakan aturan-aturan hukum dia atasnya dan menampung kondisi khusus dari daerah.

Berdasarkan hukum di atas menunjukkan bahwa Perda termasuk salah satu sumber hukum, dan di dalam tata urutan peraturan perundang-undangan menempati urutan terakhir. Berdasarkan sumber hukum di atas pula, maka diketahui bahwa Peraturan Menteri dan Keputusan Menteri tidak bersifat sebagai peraturan perundangundangan. Hal ini untuk menjamin kepastian hukum di mana sebelumnya banyak tumpang-tindih yang kadangkadang peraturan perundangundangan dikalahkan oleh peraturan menteri (Siswanto, 2006). Menurut Hamid S.Attamini dalam Siswanto (2006) "tidak semua keputusan menteri yang berisi peraturan selalu merupakan peraturan perundangundangan; tidak semua Keputusan Dirjen yang berisi peraturan perupakan peraturan perundangundangan; demikian juga tidak semua Keputusan Gubernur Kepala Daerah yang berisi peraturan dan tidak semua keputusan Bupati/Walikota Kepala Daerah yang berisi peraturan merupakan peraturan perundang undangan. Untuk itu diperlukan atribut dan delegasi kewenangan perundangundangan yang jelas.

Demikian pula terhadap peraturan kebijakan dalam bahasa Belanda, menurut Kreveld dalam Siswanto, (2006) disebut beleidsregel dengan ciri-ciri sebagai berikut : (a) Peraturan itu langsung atau tidak langsung tidak berdasar pada ketentuan formele wet ataupun grondwet yang memberikan kewenangan mengatur, dengan perkataan lain tidak mempunyai dasar hukum yang tegas dalam wet. (b) Peraturan itu tidak tertulis dan timbul oleh serangkaian putusanputusan instansi pemerintah dalam rangka penyelenggaraan kewenangan pemerintah yang bebas (vrij) terhadap perorangan, atau ditetapkan secara 
tertulis oleh instansi pemerintah tersebut; (c) Peraturan itu memberi petunjuk secara umum mengenai bagaimana instansi pemerintah tersebut akan menyelenggarakan kewenangan pemerintahan yang bebas terhadap orang perorangan yang dirumuskan dalam peraturan.

Perumusan van Kreveld di atas jelas bahwa peraturan kebijakan bukan peraturan perundang-undangan, karena tidak mempunyai dasar dalam Wet maupun dalam Grondwet. Peraturan itu timbul sebagai akibat adanya kewenangan perundang undangan. Kewenangan pemerintah mencakup kewenangan pengaturan karena sesuai fungsi negara pada umumnya meliputi fungsi perundangundangan atau fungsi legislatif, fungsi pemerintahan atau ketataprajaan atau fungsi eksekutif, dan fungsi yudikatif atau fungsi peradilan.

Fungsi pemerintahan tersebut mempunyai juga kewenangan mengatur dan melekat pada setiap pejabat dan instansi pemerintah, serta biasanya disertai dengan kewenangan menetapkan penetapan atau keputusan dalam arti beschikking atau dikenal dengan keputusan tata usaha negara. A.Hamid Attamimi dalam Siswanto (2006) mengindentifikasi terhadap persamaan dan perbedaan antara peraturan perundang undangan dan peraturan kebijakan. Persamaan Peraturan Perundang-undangan dan Peraturan kebijakan adalah (a) terletak pada unsur-unsur bahwa aturan yang berlaku dan umum; (b) Peraturan yang berlaku keluar, artinya peraturan perundang-undangan tersebut ditujukan kepada masyarakat umum demikian juga peraturan kebijakan ditujukan kepada masyarakat umum; (c) Kewenangan pengaturan yang bersifat umum/publik, dan ditetapkan oleh lembaga/pejabat yang mempunyai kewenangan umum/publik. Sedangkan perbedaannya adalah : (a) Pembentukan peraturan perundangundangan adalah fungsi negara; (b) Pembentukan peraturan kebijakan adalah fungsi pemerintah dalam arti sempit (lembaga eksekutif saja); (c) Materi muatan peraturan perundangundangan, hanya mengatur tata kehidupan masyarakat yang lebih mendasar "suruhan dan larangan" untuk berbuat atau tidak berbuat, dan apabila perlu disertai sanksi pidana dan sanksi pemaksa; (d) Peraturan kebijakan hanya mengadung materi muatan yang berhubungan dengan kewenangan membentuk keputusankeputusan dalam arti beschikkingen, yakni kewenangan bertindak dalam bidang hukum privat termasuk pula kewenangan membuat perencanaan; (e) Penerapan sanksi pidana dan sanksi pemaksa jelas akan mengurangi dan membatasi hak-hak asasi warga negara dan penduduk, dan ketentuan ini hanya dapat dituangkan dalam undang-undang yang pembentukannya harus dilakukan dengan persetujuan rakyat atau dengan persetujuan wakil-wakil rakyat; (g) Peraturan perundangundangan yang lebih rendah lainnya hanya dapat mencantumkan sanksi pidana bagi pelanggaran, apabila ketentuannya secara tegas ada atribusi oleh undang-undang. Peraturan kebijakan hanya dapat mencantumkan sanksi administratif bagi pelanggaran ketentuan-ketentuannya.

Pemahaman terhadap peraturan perundang-undangan dan peraturan kebijakan di atas dalam hubungannya dengan fungsi pemerintahan, akan 
menimbulkan permasalahan terhadap asas-asas hukum tersebut.

Dalam suatu negara berdasarkan atas hukum material atau sosial yang bertekad memajukan kesejahteraan umum dan mencerdaskan kehidupan bangsa maka penegakan hukum peraturan perundang-undangan tidak dapat dicegah. Oleh sebab itu terjadinya ledakan peraturan kebijakan tersebut tidak dapat dihindari. Hal ini dilatarbelakangi karena hampir semua lembaga atau pejabat pemerintahan dari atas sampai ke bawah, baik besar maupun kecil, merasa memiliki kewenangan membentuk peraturan kebijakan dan dapat dipastikan bahwa semua lembaga dan pejabat berpeluang membentuk peraturan tersebut untuk bidangnya masingmasing.

Kewenangan pembentukan peraturan perundang-undangan apabila dialihkan harus melalui atribusi atau delegasi yang tegas dan jelas. Kewenangan pembentukan peraturan kebijakan selalu dapat dialihkan secara tidak langsung karena yang dialihkan secara langsung adalah kewenangan penyelenggaraan pemerintahan saja, demikian juga pengalihan itu dapat dilakukan melalui atribusi dan delegasi atas dasar pemberian mandat, baik mandat itu diberikan khusus untuk bidang pengambilan keputusan, bidang pelaksanaan maupun bidang penandatanganan.

Peraturan kebijakan merupakan peraturan yang berada dalam lingkup penyelenggaraan kewenangan pemerintahan dalam arti sempit (ketataprajaan) dan peraturan ini bukan kewenangan perundang undangan. Peraturan tersebut tidak dapat bergerak terlalu jauh sehingga mengurangi hak asasi warga negara dan penduduk. Peraturan tersebut tidak dapat mencantumkan sanksi pidana atau sanksi pemaksa bagi pelanggaran ketentuan-ketentuan. Sanksi-sanksi tersebut merupakan wewenang peraturan perundangundangan, dan kewenangan tersebut diatribusikan atau didelegasikan secara tegas dan benar. Peraturan kebijakan hanya mungkin mengandung sanksi administrasi bagi pelanggar ketentuan-ketentuannya.

Berdasarkan uraian tersebut di atas, menunjukkan bahwa Perda sebagai salah satu sumber hukum, maka Perda dikatagorikan sebagai peraturan perundang-undangan, sedangkan peraturan pelaksanaannya dikatagorikan sebagai peraturan kebijakan, seperti Keputusan Kepala Daerah dan sebagainya.

\section{Kedudukan Perda}

Sejak berlakukan Undang Undang Nomor 22 tahun 1999 tentang Pemerintahan Daerah, kemudian dikenal sebagai undang-undang otonomi daerah di era reformasi sebagai pengganti Undang-Undang Nomor 5 tahun 1994 tentang PokokPokok Pemerintahan Di Daerah yang dikenal sentralistik, yang dapat ditafsirkan sebagai pokok-pokok pemerintahan pusat yang dilaksanakan di daerah, kemudian undang-undang Nomor 22 tahun 1999 mengalami perbaikan dengan diundangkannya Undang-Undang Nomor 32 tahun 2004 tentang Pemerintahan Daerah, maka semakin memantapkan kedudukan daerah dalam berotomi. Undang-undang tersebut dimaksudkan sebagai pendobrak keadaan sebelumnya yang sentralistik, sehingga penyelenggaraan pemerintahan di era ini lebih 
menampakkan keadaan yang demokratik partisipatif, menampakkan kecenderungan yang kontaministik (Murtir Jeddawi (2008).

$$
\text { Lahirnya Undang-Undang }
$$

Nomor 32 Tahun 2004 sebagai pengganti Undang-Undang Nomor 22 tahun 1999, pada dasarnya dimaksudkan untuk mencapai tujuan demokrasi dan kesejahteraan. Tujuan demokrasi akan memposisikan pemerintah daerah sebagai instrumen pendidikan politik di tingkat lokal yang secara agregat mendukung terciptanya kemantapan persatuan dan kesatuan bangsa serta mempercepat terwujudnya masyarakat madani atau civil society. Tujuan kesejahteraan mengisyaratkan pemerintah daerah untuk meningkatkan kesejahteraan masyarakat lokal melalui penyediaan pelayanan publik secara efektif, efisien dan ekonomis.

Pelaksanaan otonomi daerah sejak diundangkannya undang-undang pemerintahan daerah seperti tersebut di atas telah memberikan kewenangan yang luas bagi daerah dalam menyusun berbagai kebijakan daerah berdasarkan aspirasi dan kebutuhan masyarakat di daerah. Kebijakankebijakan daerah tersebut tercermin dalam berbagai produk hukum daerah, baik yang berbentuk Perda maupun peraturan bupati.

Pada salah satu sisi, luasnya kewenangan daerah untuk menyusun kebijakan daerah melalui Perda sangat positif, karena sebagai dasar legitimasi bagi pelaksanaan berbagai kebijakan daerah. Namun demikian, sejak otonomi daerah dilaksanakan terdapat sejumlah masalah khususnya yang berkaitan dengan produk hukum daerah karena semangat untuk melahirkan produk hukum daerah tidak diimbangi dengan kemampuan menjaga kualitas materi muatannya, penyusunan Perda tidak melibatkan publik secara luas, institusi pembuat Perda yang kurang siap karena sumber daya manusia tidak memadai dan budaya atau perilaku pejabat daerah yang keliru memaknai otonomi daerah. Oleh karena itu, menurut Moenta (2003) bahwa pertimbangan yang paling umum digunakan oleh perancang dalam pembuatan Perda ialah berorientasi pada tuntutan jangka pendek yaitu bagaimana memenuhi target-target peningkatan PAD, sementara tujuan jangka panjang berupa peningkatan pelayanan, kesejahteran masyarakat dan pembangunan masyarakat kurang mendapat pertimbangan utama dalam pembuatan Perda. Hal ini ada keterkaitan dengan lemahnya SDM sehingga interes dan peluang jangka pendek sangat menonjol. Akibat lebih jauh bahwa proses-proses pengambilan kebijakan justru memarjinalkan prinsip-prinsip good governance khususnya prinsip akuntabilitas, transparansi dan partispasi.

\begin{tabular}{lr}
\multicolumn{1}{c}{ Ketidakmampun } & pemerintah \\
daerah di & dalam \\
mengimplementasikan & kebijakan- \\
kebijakannya & termasuk \\
mengimlementasikan & Perda
\end{tabular}
disebabkan oleh berbagai faktor intenal, misalnya kurangnya dukungan dana, terbatasnya sumber daya manusia yang akan menanganinya, serta kondisi sosial budaya masyarakat setempat yang kurang mendukung. Implementasi kebijakan atau Perda memang sudah dipahami secara abstrak dan seolah-olah dapat dilaksanakan, padahal dalam praktek pelaksanaannya senantiasa menuntut 
adanya ketersediaan sumber daya (sumber-sumber kebijakan) sebagai kondisi yang dibutuhkan untuk menjamin kelancaran implementasi kebijakan (Murtir Jeddawi, 2008). Selain daripada itu Siswanto (2006) mengutip pendapat Mac Andrews bahwa "adanya kekurangberhasilan dalam mengimplementasikan kebijakan yang sering dijumpai, antara lain dapat disebabkan adanya keterbatasan sumberdaya, struktur yang kurang memadai dan kurang efektif, serta komitmen yang rendah dikalangan pelaksana", dalam hal ini termasuk pula ketidakmampuan administrasi pemerintah daerah dalam melaksanakan kebijakan atau Perda yang telah diundangkannya.

Menurut Bryant dan White yang dikutip Murtir Jeddawi (2008) bahwa ketidak mampuan administratif adalah ketidak mampuan untuk menanggapi kebutuhan-kebutuhan yang disampaikan oleh rakyat yang dapat meliputi (a) Terlalu sedikit tenaga terampil yang masih dapat ditempatkan di daerah-daerah pedesaan, walaupun diketahui bahwa di sanalah terdapat kebutuhan paling dasar; (b) Para administrator yang mampu dan sedikit jumlahnya terus menerus bergerak tersendat-sendat antara tugas-tugas dan departemendepartemen; (c) Kebanyakan departemen sangat sentralisasi dan tidak memiliki struktur yang serius untuk menjangkau wilayah-wilayah yang jauh, kendati mempunyai komitmen untuk melakukan hal itu; (d) Lembaga-lembaga tingkat lokal sangat lemah dan senantiasa diterlantarkan oleh departemendepartemen yang tersentralisasi dan karena kurangnya staf; (e) Jarak sosial antara administrator dengan masyarakat melebar dari waktu ke waktu.

Kondisi dan fakta yang sering terjadi dalam penyusunan Perda seperti tersebut di atas menyebabkan Perda-Perda yang dihasilkan oleh daerah bermasalah dalam banyak aspek pada implementasinya. Padahal rancangan Perda yang ideal adalah produk hukum daerah menjamin kepastian hukum, menjamin terlaksananya HAM, tidak bertentangan dengan hirarki perundang-undangan yang lebih tinggi dan diterima serta dapat terlaksana dengan baik.

Oleh karena itu suatu Perda diharapkan mengakomudir segala hal yang berkaitan dengan otonomi daerah yang bertanggungjawab, seperti dijelaskan sebelumnya sehingga di dalam implementasinya tidak menimbulkan penolakan-penolakan ditengah-tengah masyarakat, mengingat kedudukan Perda merupakan peraturan untuk melaksanakan aturan hukum di atasnya dan menampung kondisi khusus di daerah. Perda idealnya merupakan komitmen bersama dari komponen daerah dalam menyepakati pengaturan, pembatasan maupun pelaksanaan bidang-bidang tertentu. Pemerintah daerah dan DPRD dalam mengajukan konsep rancangan Perda tentunya berangkat dari permasalahan yang dirasakan berbeda dengan kondisi yang diharapkan.

\section{Fungsi Perda}

Sebagai daerah otonom pemerintah daerah berwenang untuk membuat Perda guna menyelenggarakan urusan otonomi daerah dan tugas pembantuan. Perda ditetapkan oleh Kepala Daerah, setelah mendapat persetujuan 
bersama DPRD. Substansi atau muatan materi Perda adalah penjabaran dari peraturan perundangundangan yang tingkatannya lebih tinggi, dengan memperhatikan ciri khas masing-masing daerah.

Fungsi Perda terutama untuk merumuskan masalah yang dihadapi Pemda dalam melaksanakan otonomi dan pembangunan daerah, terutama masalah sosial sebagai perilaku masyarakat, misalnya banyak masyarakat membuang sampah disembarangan tempat sehingga menyebabkan lingkungan menjadi kumuh maka diperlukan Perda Kebersihan. Banyak orang mabuk karena mengkonsumsi minuman kadar alkohol yang tinggi maka diperlukan pengaturan tentang peredaran minuman beralkohol. Rusaknya bangunan bersejarah / bangunan kuno karena dirobohkan atau diganti dengan bangunan baru yang menghilangkan ciri khas bangunan lama maka diperlukan Perda tentang Cagar budaya. Selain itu juga masalah yang disebabkan karena aturan hukum yang ada tidak lagi proporsinal dengan keadaan masyarakatnya, misalnya Perda tentang Retribusi biaya pemeriksaan kesehatan, ternyata memberatkan masyarakat kecil sehingga tidak memperoleh pelayanan kesehatan yang memadai. Perda tentang Pajak Daerah yang tidak sesuai dengan Undang-Undang tentang Pajak Daerah maka Perda tersebut harus diganti dengan yang baru.

Perda dan Keputusan Daerah merupakan bagian penting dari proses politik oleh daerah, yang memuat ketentuan dengan kepentingan umum, Perda lain, dan peraturan perundangundangan yang lebih tinggi. Perda memuat ketentuan tentang pembebanan biaya paksaan penegakan hukum, seluruhnya atau sebagian kepada pelanggar. Paksaan yang dilakukan Perda untuk menegakkan hukum disebut paksaan penegakan hukum atau paksaan pemeliharaan hukum. Paksaan harus didahului oleh suatu perintah tertulis oleh penguasa eksekutif kepada pelanggar. Apabila pelanggar tidak mengindahkannya, diambil suatu tindakan paksaan.

Selain daripada itu, Perda juga dapat memuat ancaman pidana kurungan paling lama 6 bulan atau denda sebanyak-banyaknya Rp.5.000.000,-- Untuk melaksanakan Perda maka dan atas kuasa peraturan perundang-undangan lain yang berlaku, Kepala Daerah menetapkan Keputusan Daerah. Oleh karena itu setiap suatu Perda dicabut dan digantikan Perda yang baru karena tidak sesuai lagi dengan keadaan yang sedang berkembang dalam masyarakat maka seringakali atau selalu diikuti oleh penetapan Keputusan Daerah yang baru pula untuk melaksanakan Perda yang baru itu.

Namun demikian Perda yang baru sebagai pengganti Perda yang lama haruslah memiliki yuridiksi sehingga kondisional dan diterima oleh masyarakat di daerah tersebut.

Menurut Siswanto Sunarno (2006), bahwa Perda memiliki hak yuridiksi setelah diundangkan dalam lembaran daerah, dan pembentukan Perda berdasarkan asas pembentukan peraturan perundang-undangan, yang secara garis besar mengatur tentang : (a) kejelasan tujuan; (b) kelembagaan atau organ pembentuk yang tepat; (c) kesesuaian antara jenis dan materi muatan; (d) dapat dilaksanakan; (e) 
kedayagunaan dan kehasilgunaan; (f) kejelasan rumusan; (g) keterbukaan. Selanjutnya Siswanto Sunarno (2006) menyebutkan materi muatan Perda mengandung asas (a) pengayoman; (b) kemanusiaan; (c) kebangsaan; (d) kekeluargaan; (e) kenusantaraan; (f) bhineka tunggal ika; (g) keadilan; (h) kesamaan kedudukan dalam hukum dan pemerintahan; (i) ketertiban dan kepastian hukum; (j) keseimbangan, keserasian, dan keselarasan; (k) asasasas lain sesuai substansi Perda yang bersangkutan.

Dalam proses pembuatan Perda, masyarakat berhak memberikan masukan secara lisan atau tertulis dalam rangka penyiapan atau pembahasan rancangan Perda. Rancangan Perda harus berpedoman kepada peraturan perundangundangan. Rancangan Perda dapat berasal dari DPRD, Gubernur atau Bupati/Walikota. Apabila dalam satu masa sidang, DPRD dan Gubernur atau Bupati/Walikota menyampaikan rancangan Perda, mengenai materi yang sama maka yang dibahas adalah rancangan Perda yang disampaikan oleh DPRD, sedangkan rancangan Perda yang disampaikan Gubernur atau Bupati/Walikota digunakan sebagai bahan untuk dipersandingkan.

Ketentuan tentang tata cara mempersiapkan rancangan Perda yang berasal dari Gubernur atau Bupati/Walikota diatur dengan Peraturan Presiden, sedangkan tata cara mempersiapkan rancangan Perda oleh DPRD diatur dalam peraturan tata tertib DPRD. Rancangan Perda agar memperoleh masukan dari masyarakat atau para pakar maka untuk rancangan Perda yang berasal dari DPRD dilaksanakan oleh sekretariat DPRD (Sekwan), sedangkan Perda yang berasal dari Gubernur atau Bupati/Walikota disebarluaskan oleh sekretariat daerah.

Muatan materi Perda dapat memuat ketentuan tentang pembebanan biaya paksaan penegakan hukum (dwangsom) seluruhnya atau sebagian kepada pelangggar sesuai dengan peraturan perundangundangan. Perda dapat memuat ancaman pidana kurungan paling lama enam bulan, atau denda paling banyak Rp.5.000.000,-- (lima juta rupiah), dan dapat pula memuat ancaman pidana atau denda lain, sesuai dengan yang diatur dalam peraturan perundangan lainnya

Rancangan Perda yang telah disetujuan bersana oleh DPRD dan Gubernur atau Bupati/Walikota, disampaikan oleh pimpinan DPRD kepada Gubernur atau Bupati/Walikota untuk ditetapkan sebagai Perda. Penyampaian rancangan Perda tersebut, dilakukan dalam jangka waktu paling lama tujuh hari terhitung sejak tanggal persetujauan bersama. Rancangan Perda ditetapkan oleh Gubernur, Bupati/Walikota paling lama 30 hari sejak rancangan tersebut disetujui bersama. Apabila rancangan Perda yang tidak ditetapkan oleh Gubernur atau Bupati/Walikota dalam waktu paling lama 30 hari, Perda tersebut sah menjadi Perda dan wajib diundangkan dengan memuatnya pada lembaran daerah. Pengesahan Perda harus dirumuskan dengan kalimat pengesahan yang berbunyi "Perda ini dinyatakan sah", dengan mencantumkan tanggal sahnya dan kalimat pengesahan itu harus dibubuhkan pada halaman terakhir Perda, sebelum pengundangan naskah Perda ke dalam lembaran daerah. 
Sebagai upaya pengawasan terhadap Perda oleh pemerintah, paling lama tujuh hari setelah ditetapkan, Perda tersebut harus disampaikan kepada pemerintah, karena Perda yang dinyatakan bertentangan dengan kepentingan umum, dan/atau peraturan perundang undangan yang lebih tinggi dapat dibatalkan oleh pemerintah. Keputusan pembatalan Perda tersebut ditetapkan dengan Peraturan Presiden paling lama 60 hari sejak diterima Perda yang dimaksud. Paling lama tujuh hari setelah keputusan pembatalan Perda yang dimaksud, kepala daerah harus memberhentikan pelaksanaan Perda dan selanjutnya DPRD bersama kepala daerah mencabut Perda dimaksud.

Apabila propinsi/kabupaten/kota tidak dapat menerima keputusan pembatalan Perda yang dimaksud, dengan alasan yang dapat dibenarkan oleh peraturan perundang-undangan Kepala Daerah dapat mengajukan keberatan kepada Mahkamah Agung (MA). Jika keberatan itu dikabulkan sebagian atau seluruhnya, putusan Mahkamah Agung (MA) tersebut menyatakan bahwa Peraturan Presiden menjadi batal dan tidak mempunyai kekuatan hukum. Demikian pula apabila pemerintah tidak mengeluarkan Peraturan Presiden untuk membatalkan Perda dimaksud, Perda dinyatakan berlaku.

Untuk melaksanakan Perda dan atas kuasa peraturan perundangundangan Kepala Daerah menetapkan Peraturan Kepala Daerah dan atau Keputusan Kepala Daerah. Peraturan Kepala Daerah dan/atau Keputusan Kepala Daerah, dilarang bertentangan dengan kepentingan umum, Perda, dan peraturan perundang-undangan yang lebih tinggi. Peraturan Kepala Daerah diundangkan dalam berita daerah yang dilakukan oleh Sekretaris Daerah.

Pemerintah daerah wajib menyebarluaskan Perda yang telah diundangkan dalam lembaran daerah dan Peraturan Kepala Daerah yang telah diundangkan dalam berita daerah. Untuk menegakkan Perda, dibentuk satuan polisi pamong praja yang bertugas membantu kepala daerah untuk menegaggak Perda dan penyelenggaraan ketertiban umum dan ketentraman masyarakat. Anggota Satuan Polisi Pamong Praja dapat diangkat sebagai penyidik pegawai negeri sipil dan penyidikan, serta penuntutan terhadap pelanggaran atas ketentuan Perda dilakukan oleh pejabat dan penuntut umum sesuai ketentuan peraturan perundangundangan. Untuk menegakkan Perda maka dapat ditunjuk pejabat lain yang diberi tugas untuk melakukan penyidikan terhadap pelanggaran atas ketentuan Perda.

\section{Kesimpulan}

1. Perda sebagai sebagai salah satu instrumen hukum daerah memiliki fungsi yang demikian vital dalam menunjang kelancaran penyelenggaraan pemerintahan otonomi daerah yang bertanggungjawab.

2. Melalui Ketetapan MPR RI Nomor III Tahun 2000, memperkuat pengakuan pemerintah akan eksistensi Perda masuk dalam tata urutan perundangundangan di negeri ini. Perda adalah peraturan untuk melaksanakan aturanaturan hukum diatasnya dan menampung kondisi khusus di daerah.

3. Berdasarkan Undang-Undang Nomor 10 tahun 2004 Tentang Pembentukan Peraturan Perundang-undangan, maka 
Perda adalah Peraturan PerundangUndangan yang dibentuk oleh DPRD dengan persetujuan bersama Kepala Daerah. Kepala Daerah menetapkan Perda atas persetujuan DPRD dalam rangka penyelenggaraan Otonomi Daerah dan penjabaran lebih lanjut dari peraturan perundang-undangan yang lebih tinggi. Oleh karena itu Perda tidak boleh bertentangan dengan kepentingan umum, Perda lainnya dan peraturan perundang-undangan yang lebih tinggi.

4. Untuk melaksanakan Perda dan atas kuasa peraturan perundang-undangan lain yang berlaku, Kepala Daerah menetapkan keputusan Kepala Daerah. Perda dan keputusan Kepala Daerah bersifat mengatur diundangkan dengan menempatkannya dalam Lembaran Daerah.

\section{DAFTAR PUSTAKA}

Rasyid, Ryaas, 1997, Makna Pemerintahan, Yasrif Watampone, jakarta.

Riwu Kaho, 1982, Analisis Hubungan Pemerintah Pusat dan Daerah di Indonesia, Bina Aksara, Jakarta

Husen, La Ode. "Negara Hukum, Demokrasi dan Pemisahan Kekuasaan." (2009).
Nawi, Rusdin. "Pengaruh Kebijakan Publik terhadap Kualitas Pelayanan, penguatan Kelembagaan dan Kinerja Organisasi Pemerintahan." Pleno Jure 4.5 (2015): 42-55.

Sampara, Said. "Fungsi Pengawasan Mahkamah Agung Dalam Penyelenggaraan Peradilan Yang Imparsial." Jurnal AlIshlah 19.1 (2017).

Siswanto Sunarno, 2006, Hukum Pemerintahan Daerah Di Indonesia, Sinar Grafika, Jakarta.

Majelis Permusyawaratan Rakyat, Tap MPR No.III Tahun 2000 tentang Sumber Hukum dan Tata Urutan Peraturan Perundangundangan.

Murtir Jeddawi, 2008, Implementasi Kebijakan Otonomi Daerah, Kreasi Total Media, Yokyakarta.

Undang-Undang No.22 Tahun 1999, tentang Pemerintahan Daerah, Departemen Dalam Negeri Republik Indonesia, Jakarta

Undang-Undang No.32 Tahun 2004, tentang Pemerintahan Daerah, Cipta Umbara, Bandung. 